\title{
Isolation and Identification of an Efficient Aerobic Denitrifying Pseudomonas stutzeri Strain and Characterization of Its Nitrite Degradation
}

\author{
Weilai Fu 1,2, ${ }^{+}$, Qiang Wang 1,+, Shuhui Chen ${ }^{1}$, Yunshuang Wang ${ }^{2}$, Yaru Wang ${ }^{2}$, Peifeng Duan ${ }^{2}$, Ganfeng Yi 1,2, \\ Chao Liu ${ }^{1}$, Xian Zhang ${ }^{1, *}$ and Zhiming Rao ${ }^{1, *(D)}$ \\ 1 The Key Laboratory of Industrial Biotechnology, Ministry of Education, School of Biotechnology, \\ Jiangnan University, Wuxi 214122, China; fuweilai0313@163.com (W.F.); wangqiang032201@163.com (Q.W.); \\ chen_shuhui_99@163.com (S.C.); Yigf@hotmail.com (G.Y.); histliuchao@163.com (C.L.) \\ 2 The Key Laboratory of Functional Aquafeed and Culture Environment Control, Fujian DBN Aquatic Science \\ and Technology Co., Ltd., Zhangzhou 363500, China; wyshuang_cris@163.com (Y.W.); \\ wangjiayi910204@163.com (Y.W.); duanpeifeng0908@126.com (P.D.) \\ * Correspondence: zx@jiangnan.edu.cn (X.Z.); raozhm@jiangnan.edu.cn (Z.R.); Tel.: +86-0510-85916881 (X.Z.); \\ Fax: +86-0510-85918516 (X.Z.) \\ + Authors contributed equally to this study.
}

check for updates

Citation: Fu, W.; Wang, Q.; Chen, S.; Wang, Y.; Wang, Y.; Duan, P.; Yi, G.; Liu, C.; Zhang, X.; Rao, Z. Isolation and Identification of an Efficient Aerobic Denitrifying Pseudomonas stutzeri Strain and Characterization of Its Nitrite Degradation. Catalysts 2021 11, 1214. https://doi.org/10.3390/ catal11101214

Academic Editor: Anwar Sunna

Received: 9 September 2021

Accepted: 6 October 2021

Published: 9 October 2021

Publisher's Note: MDPI stays neutral with regard to jurisdictional claims in published maps and institutional affiliations.

Copyright: (c) 2021 by the authors. Licensee MDPI, Basel, Switzerland. This article is an open access article distributed under the terms and conditions of the Creative Commons Attribution (CC BY) license (https:// creativecommons.org/licenses/by/ $4.0 /)$

\begin{abstract}
Nitrogen pollution in water bodies is becoming increasingly serious, and how to remove nitrogen from water bodies economically and effectively has become a research hotspot. Especially in recent years, with the gradual expansion of aquaculture in China, the content of nitrite and other nitrogen-containing substances in water bodies has been increasing, which inhibits the growth of farm animals and is one of the causes of eutrophication in water bodies. In this study, a strain of bacteria was isolated from the sludge of an aquaculture fishpond and identified as Pseudomonas stutzeri, which can efficiently degrade nitrite. After continuous domestication in nitrite mixed solution, the nitrite nitrogen reduction capacity of $P$. stutzeri was significantly improved. Univariate experiments aiming to optimize the degradation conditions indicate that the optimal culture conditions for strain $\mathrm{F} 2$ are: medium with a carbon source of sodium succinate; $\mathrm{C} / \mathrm{N}$ of $18 ; \mathrm{pH}$ of 8 ; culture temperature of $28^{\circ} \mathrm{C}$; and shaking speed of $210 \mathrm{rpm}$ in the shaker. Under the optimal culture conditions, the $\mathrm{NO}_{2}{ }^{-}-\mathrm{N}$ concentration of the culture solution was $300 \mathrm{mg} / \mathrm{L}$, and the nitrite removal rate reached $98.67 \%$. Meanwhile, the results of the nitrogen balance test showed that the strain converted $6.1 \%$ of the initial nitrogen into cellular organic nitrogen and $62.3 \%$ into gaseous nitrogen.
\end{abstract}

Keywords: nitrogen pollution; nitrite removal; domestication; Pseudomonas stutzeri

\section{Introduction}

In the aquaculture process, there is often a large amount of aquatic animal excrement, residual bait, and dead biological residues deposited on the bottom of the pond, resulting in the deterioration of the pond aquaculture water quality, the concentration of nitrogen such as sub-nitrate nitrogen in the water column seriously exceeding the standard amount, and the proliferation of harmful microorganisms [1]. Animals in the ponds are subject to long-term stress, resulting in increasingly serious disease, which not only causes huge economic losses to aquaculture farmers, but also gives rise to a series of aquatic product quality and safety issues. To reduce the harm caused by nitrite nitrogen and other nitrogen pollution, people often use water changes, aeration, drugs, and other methods of treatment, but there are great limitations, as these methods have high costs, a short duration, and require the use of drugs to make the germs drug resistant, as well as other disadvantages. Therefore, the search for new models of healthy aquaculture and the development of environmentally friendly products with disease control and water quality improvement has become a hot spot for research in the field of aquaculture. Many scholars believe 
that the most thorough way to restore an imbalanced pond ecosystem is to use microbial remediation methods $[2,3]$.

Biological denitrification technology is the most effective denitrification technology due to its simple operation, low cost, and low secondary pollution [4,5]. The traditional biological denitrification theory suggests that the nitrification process is performed by aerobic autotrophic nitrifying bacteria, the denitrification process is performed by anoxic heterotrophic denitrifying bacteria, and the nitrification and denitrification processes occur in two separate environments and cannot be carried out in the same system. Therefore, traditional biological denitrification is not suitable for water source reservoirs. In the 1980s, Robertson et al. [6] successfully isolated Thiosphera pantotropha (now known as Paracoccus sp.), a denitrifying bacterium under aerobic conditions, from a Dutch desulfurization and denitrification system. This finding shows that nitrification and denitrification can take place in the same environment, while the alkali produced during denitrification can balance the acid produced during nitrification, and no additional acid or alkali is needed to neutralize the system during operation, opening up a new area of research [7].

With the continuous progress of research, some aerobic denitrifying bacteria, mainly Alcaligenes [8], Paracoccus [9], Pseudomonas [10], and Bacillus [11], have been isolated by domestic and foreign researchers. Among them, the most prevalent aerobic denitrifying bacteria in the environment are Pseudomonaceae, Alcaligenes, Paracoccus, etc. [12]. On the whole, the current research on heterotrophic nitrification-aerobic denitrification bacteria at home and abroad is still in the laboratory stage, including resource mining, denitrification characteristic research, denitrification mechanism research, and denitrification effect evaluation of simulated wastewater under aseptic conditions, while the practical application research in cultured water bodies is even more scarce $[13,14]$.

In this study, highly active aerobic denitrifying bacteria were isolated and screened from the natural environment, and then continuously domesticated in different concentrations of nitrite mixed salt cultures to further improve their denitrification performance. Their culture conditions were optimized to achieve the best denitrification performance. This provides a theoretical basis and experimental data for research applications in aquaculture and helps the development and commercialization of microecological preparations, which has important theoretical research significance and practical application value.

\section{Results and Discussion}

\subsection{Strain Selection}

By testing the growth curve and nitrogen reduction performance of 10 aerobic denitrifying bacteria strains, it was found that strain F2 had efficient nitrogen reduction performance. Its growth rate and denitrification efficiency were much higher than other strains, and the bacterial concentration $\left(\mathrm{OD}_{600}\right.$ value) could reach 1.02 (Figure $\left.1 \mathrm{~A}\right)$. Under the condition of a nitrite nitrogen concentration of $300 \mathrm{mg} / \mathrm{L}$, and a shake flask fermentation culture for $36 \mathrm{~h}$, the nitrite denitrification rate could reach $72.6 \%$ (Figure 1B). Therefore, strain F2 was retained, and its strain identification and culture degradation conditions were optimized.

\subsection{Identification of Strain F2}

In the preliminary screening experiments, strain F2 showed the highest efficiency in the removal of nitrite. Strain F2 was Gram-negative, non-motile, and had a short rod shape. The mature colonies of strain F2 were prominently aqua, rugose, round, humid, translucent, and irregularly bordered. A portion of the $16 \mathrm{~S}$ rRNA sequence of strain F2 was obtained by polymerase chain reaction (PCR). A homology search using Blast showed that strain F2 was most closely related to Pseudomonas stutzeri P3 and P. stutzeri HD4-1. Therefore, strain F2 was identified as P. stutzeri F2. Based on the adjoint method and GenBank database, a phylogenetic tree was established (Figure 2). 

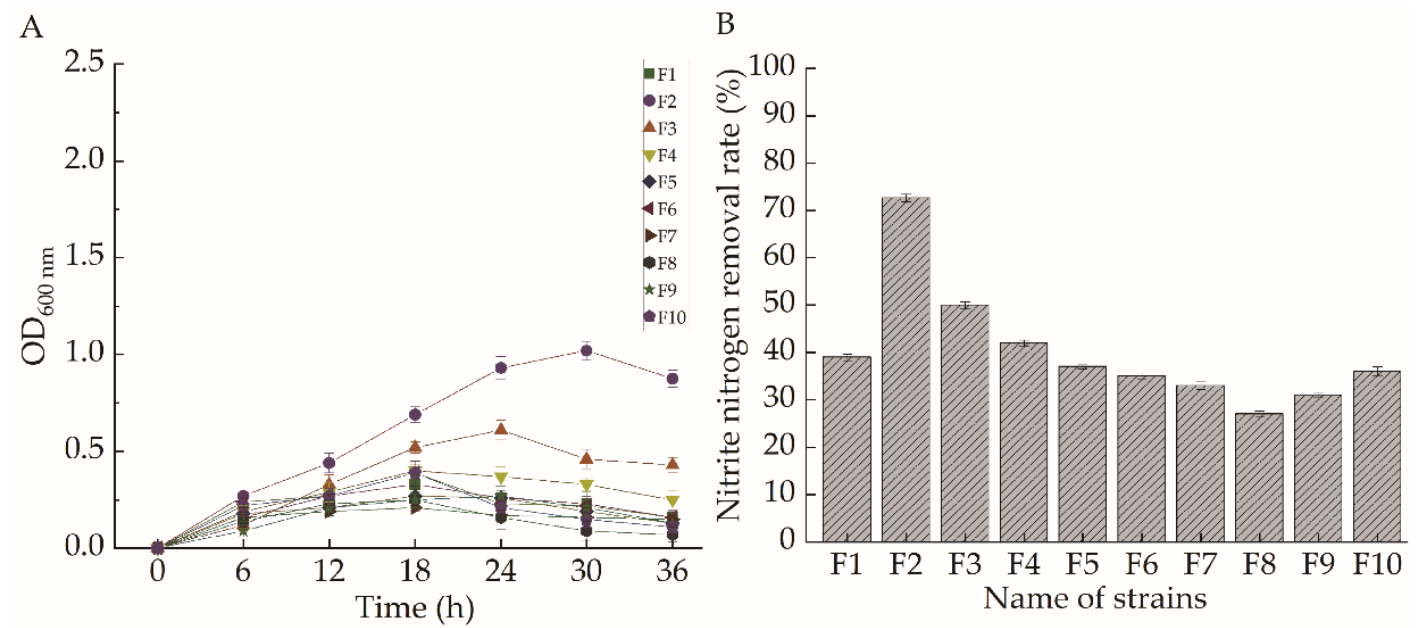

Figure 1. Growth curves (A) and nitrite denitrification rates (B) of different strains of bacteria.

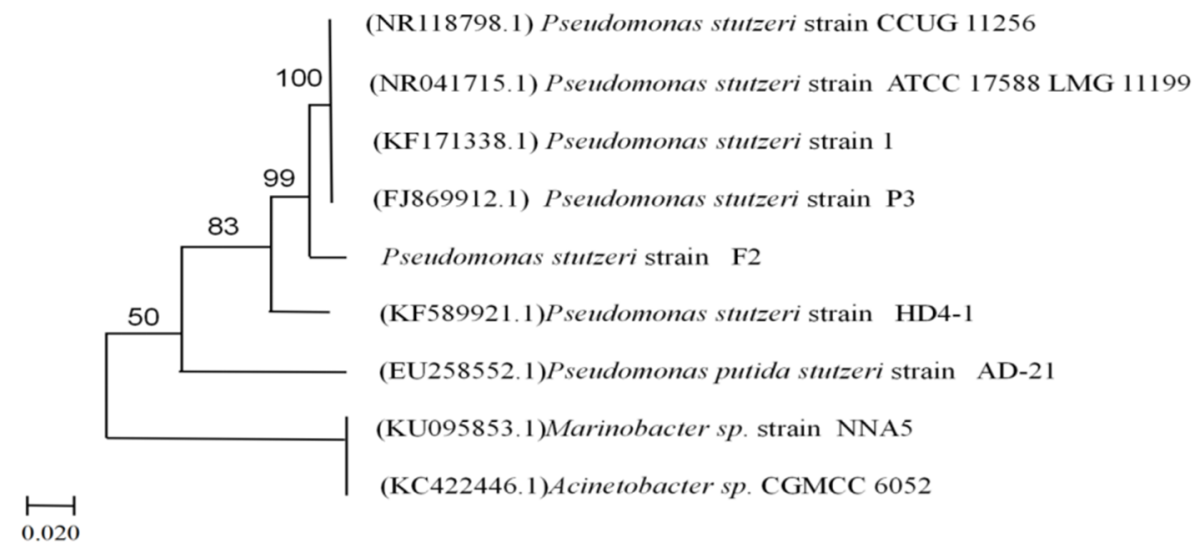

Figure 2. The phylogenetic tree of the F2 strain was obtained from neighbor-joining of partial 16S rRNA sequences, and the closed columns indicate the roots of the tree.

\subsection{Analysis of the Results of Targeted Domestication}

The nitrite tolerance of strain F2 was domesticated by the concentration gradient increment method. Before domestication, strain $\mathrm{F} 2$ was able to grow to a maximum $\mathrm{OD}_{600}$ of only 1.12 in a denitrification medium with an initial $\mathrm{NO}_{2}{ }^{-}-\mathrm{N}$ concentration of $300 \mathrm{mg} / \mathrm{L}$ (Figure 3A), while at an initial nitrosomal nitrogen concentration of $500 \mathrm{mg} / \mathrm{L}$, strain F2 barely grew. After a period of domestication, the growth of the strain improved significantly, and the corresponding maximum $\mathrm{OD}_{600}$ was $2.38,1.91$, and 1.41 at initial $\mathrm{NO}_{2}{ }^{-}-\mathrm{N}$ concentrations of 300,400 , and $500 \mathrm{mg} / \mathrm{L}$, respectively, indicating that the domesticated F2 strain has significantly increased tolerance to $\mathrm{NO}_{2}{ }^{-}-\mathrm{N}$ and can be applied to the treatment of nitrite wastewater at high concentrations.

\subsection{Aerobic Denitrification}

The growth of cells of strain $\mathrm{F} 2$ was determined by fitting $\mathrm{OD}_{600}$ with the Slogistic1 equation, $y(t)=a /\{1+\exp [-k \times(t-t c)]\}$. The coefficient of correlation (R2) was 0.99 , indicating that the Slogistic1 equation sufficiently described the growth of strain F2 (Figure 4). The results of the Origin 2020 analysis showed that the values of a, k, and tc were 1.09, 0.25, and 12.89 , respectively. 

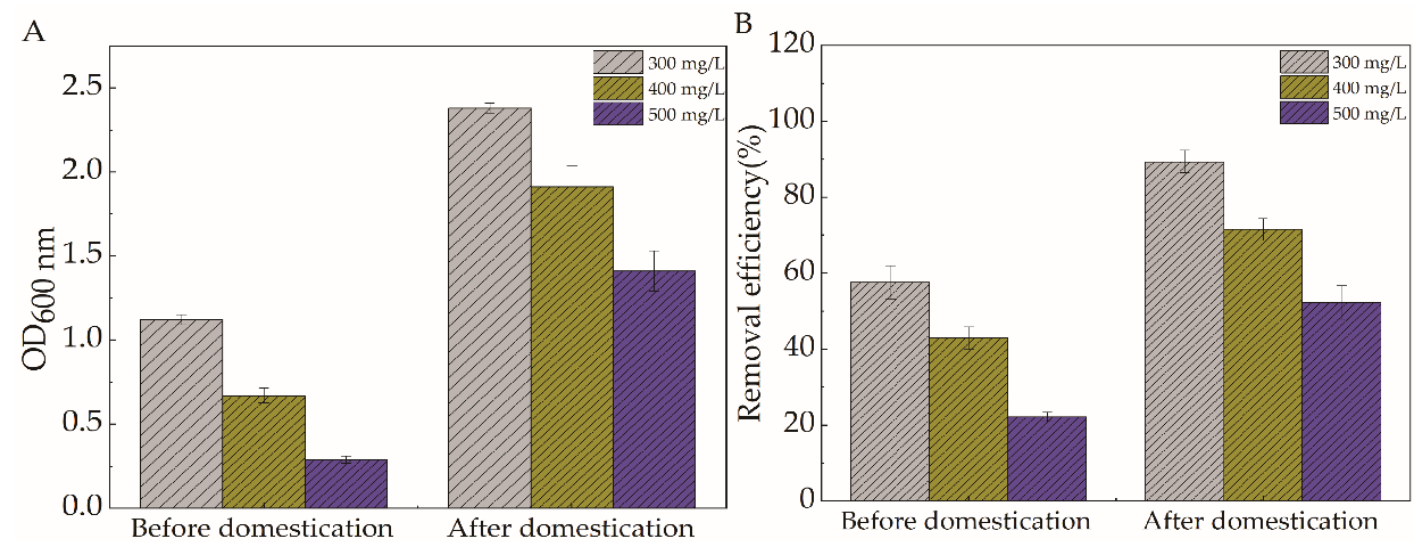

Figure 3. Variation of $\mathrm{OD}_{600}(\mathbf{A})$ and $\mathrm{NO}_{2}{ }^{-}-\mathrm{N}$ degradation efficiency (B) before and after the domestication of the strain $\mathrm{F}$.

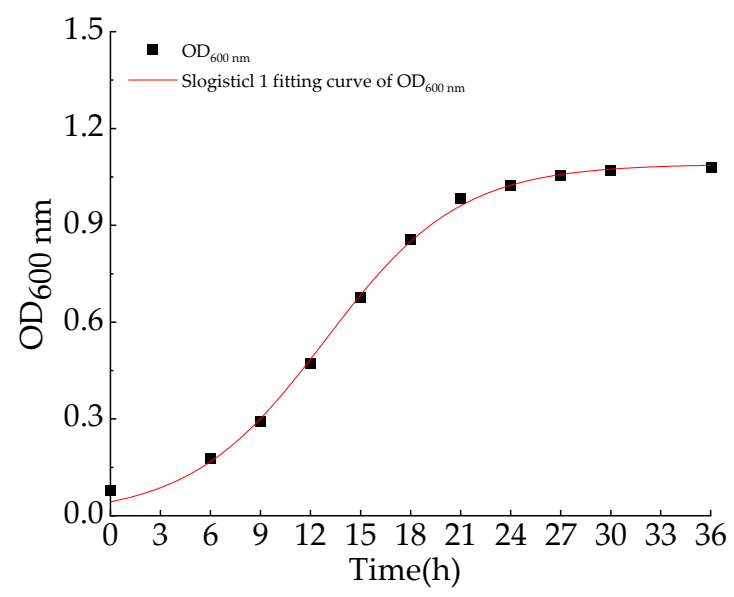

Figure 4. The characteristics of growth by P. stutzeri strain F2.

The removal efficiency of $\mathrm{NO}_{2}{ }^{-}-\mathrm{N}$ reached $76.92 \%$ in $36 \mathrm{~h}$ with an initial concentration of about $300 \mathrm{mg} / \mathrm{L}$. Nitrogen balance revealed that $6.1 \%$ of the initial $\mathrm{NO}_{2}{ }^{-}-\mathrm{N}$ was used for cell synthesis, and $71.29 \%$ was converted to gaseous nitrogen (Table 1). The production of gaseous nitrogen was similar to that of P. stutzeri XL-2 [15], which also indicated that the F2 strain did undergo aerobic denitrification.

Table 1. Nitrogen balance of P. stutzeri strain F2 under the aerobic condition.

\begin{tabular}{ccccccc}
\hline \multirow{2}{*}{$\begin{array}{c}\text { Initial } \\
\mathbf{N}\end{array}(\mathbf{m g} / \mathrm{L})$} & $\mathbf{N O}_{2}{ }^{-} \mathbf{- N}$ & $\mathbf{N O}_{3}{ }^{-}-\mathbf{N}$ & $\mathbf{N H}_{\mathbf{4}}{ }^{+}-\mathbf{N}$ & Organic $\mathbf{N}$ & Intracellular $\mathbf{N}$ & $\mathbf{G a s e o u s ~} \mathbf{N}$ \\
\cline { 2 - 7 } & $69.24 \pm 4.61$ & $5.04 \pm 0.12$ & $9.13 \pm 0.32$ & $2.73 \pm 0.11$ & $18.30 \pm 0.22$ & $213.86 \pm 5.02$ \\
\hline $300.0 \pm 4.34$ & &
\end{tabular}

2.5. Effects of Different Carbon Source Types, $\mathrm{C} / \mathrm{N}, \mathrm{pH}$, Temperature, and Dissolved Oxygen on the Efficiency of Aerobic Denitrification

\subsubsection{Different Carbon Source Types}

The carbon source is one of the essential nutrients for microbial growth, providing the cellular carbon shelf for microbial growth and metabolism, and energy for cellular life activities. For aerobic denitrifying bacteria, the carbon source affects not only their growth but also their denitrification efficiency. This is because aerobic denitrification is a redox reaction, and the carbon source not only provides the energy required by the cells during the growth of the strain, but also provides the electron donor. Different carbon sources have different redox potentials and, therefore, different abilities to provide electrons, which can have an impact on the aerobic denitrification reaction. In addition, carbon sources 
also affect the activity of enzymes involved in aerobic denitrification $[16,17]$. The chemical structure and molecular weight of the carbon source were reported to have a significant effect on the denitrification efficiency, and the strains generally preferred to utilize carbon sources with simple chemical structures and small molecular weights, such as sodium succinate and sodium citrate $[18,19]$.

To investigate the effects of different carbon sources on the growth and degradation of nitrite by strain $\mathrm{F} 2$, the initial $\mathrm{NO}_{2}{ }^{-}-\mathrm{N}$ concentration was fixed at about $300 \mathrm{mg} / \mathrm{L}$, and sodium succinate, trisodium citrate, and maltose were selected as the carbon sources for the experiment. Strain F2 was able to grow better using sodium succinate and trisodium citrate, and when the carbon source was maltose, the growth efficiency of the strain was significantly reduced, which indicated that there were differences in the growth of strain F2 under different carbon sources. Among them, strain F2 grew most vigorously in sodium succinate with $\mathrm{OD}_{600}$ of up to 2.03 (Figure $5 \mathrm{~A}$ ), followed by trisodium citrate with $\mathrm{OD}_{600}$ of up to 1.73; in the environment with maltose as the carbon source, the biomass of the strain was inhibited with a maximum of 0.65 . In the case of sodium succinate and trisodium citrate as the carbon source, strain F2 entered the logarithmic phase relatively quickly. This may be because sodium succinate and citric acid have simple chemical structures and small molecular weights; on the other hand, succinate and citric acid are intermediate products of the tricarboxylic acid cycle and are more easily utilized by microflora. From Figure $5 B, C$, it can be seen that there is a consistency among the growth of strain F2, the degradation of $\mathrm{NO}_{2}{ }^{-}-\mathrm{N}$ and the removal of $\mathrm{TN}$; the higher the density of $\mathrm{OD}_{600}$ of the bacterial solution, the higher the degradation rate of $\mathrm{NO}_{2}{ }^{-}-\mathrm{N}$ and the removal rate of $\mathrm{TN}$. The density of the bacterial solution with sodium succinate as the carbon source was significantly higher than that of the remaining two groups, and its $\mathrm{NO}_{2}{ }^{-}-\mathrm{N}$ degradation rate was $84.54 \%$ and $\mathrm{TN}$ removal rate was $78.41 \%$, which was higher than those of the culture solution with trisodium citrate and maltose as the carbon source. During the experiment, the concentration of $\mathrm{NO}_{3}{ }^{-}-\mathrm{N}$ increased and then decreased as the incubation proceeded (Figure 5D), and $\mathrm{NH}_{4}{ }^{+}-\mathrm{N}$ accumulated gradually over time, but the content was always at a low level (Figure 5E). The experimental results indicate that the carbon source affects the nitrite removal rate of the bacteria by influencing their growth, and sodium succinate was used as the carbon source in all the following experiments.

\subsection{2. $\mathrm{C} / \mathrm{N}$}

The carbon to nitrogen ratio has a great effect on the metabolism of substances and energy in bacteria [20]. Under different carbon to nitrogen ratio conditions, the denitrification ability of the strain is different. The concentration of the carbon source will directly affect the growth and aerobic denitrification performance of the strain. When the carbon source is insufficient, it will result in providing less and slower electron flow to support the growth of the strain; then, accordingly, the efficiency of aerobic denitrification will be reduced. However, when the level of the carbon source is too high, it becomes a non-limiting factor, and the growth and metabolism of the strain reach stability [21].

To investigate the effect of organic carbon source concentration on the growth and denitrification efficiency of strain $\mathrm{F} 2$, the initial $\mathrm{NO}_{2}{ }^{-}-\mathrm{N}$ was fixed at about $300 \mathrm{mg} / \mathrm{L}$, and the initial organic carbon concentration was changed to control the carbon to nitrogen mass ratio of 6,12 , and 18 . When the $\mathrm{C} / \mathrm{N}$ ratio was 6 , the maximum $\mathrm{OD}_{600}$ of the bacterium was only 1.71 (Figure 6A) and the nitroso-nitrogen degradation rate was $66.33 \%$. When the $\mathrm{C} / \mathrm{N}$ increased to 12 , the biomass of the bacterium increased significantly and was in the late logarithmic growth stage. The nitroso-nitrogen denitrification rate reached $84.47 \%$, and the $\mathrm{NO}_{2}{ }^{-}-\mathrm{N}$ removal efficiency was higher. When the $\mathrm{C} / \mathrm{N}$ ratio increased from 12 to 18 , there was a slight increase in the biomass of $\mathrm{F} 2$. The change was not particularly prominent, and almost all $\mathrm{NO}_{2}{ }^{-}-\mathrm{N}$ nitrogen sources could be effectively reduced. In addition, nitrate- $\mathrm{N}$ and ammonia- $\mathrm{N}$ were gradually detected after $6 \mathrm{~h}$ of inoculation, and the concentration of nitrate- $\mathrm{N}$ reached its peak at $18 \mathrm{~h}$. With the increase in fermentation time, the concentration of nitrate- $\mathrm{N}$ gradually decreased and was always below $10 \mathrm{mg} / \mathrm{L}$ in all groups (Figure 6D). 
The concentration of ammonia nitrogen exhibited an increasing trend in the first $36 \mathrm{~h}$ and still showed a small inward increase at $36 \mathrm{~h}$. Then, we continued to monitor the medium for an extended period of time and found that the content of $\mathrm{NH}_{4}{ }^{+}-\mathrm{N}$ gradually began to decrease after $36 \mathrm{~h}$, which kept the concentration of $\mathrm{NH}_{4}{ }^{+}-\mathrm{N}$ at a low level (Figure $6 \mathrm{E}$ ). In addition, Roberson et al. [6] also confirmed that the higher the concentration of the carbon source as an energy source in a certain concentration range, the faster the aerobic denitrification rate, which is consistent with the results of this study. In the following experiments, $\mathrm{C} / \mathrm{N}$ conditions were all controlled to 18 .
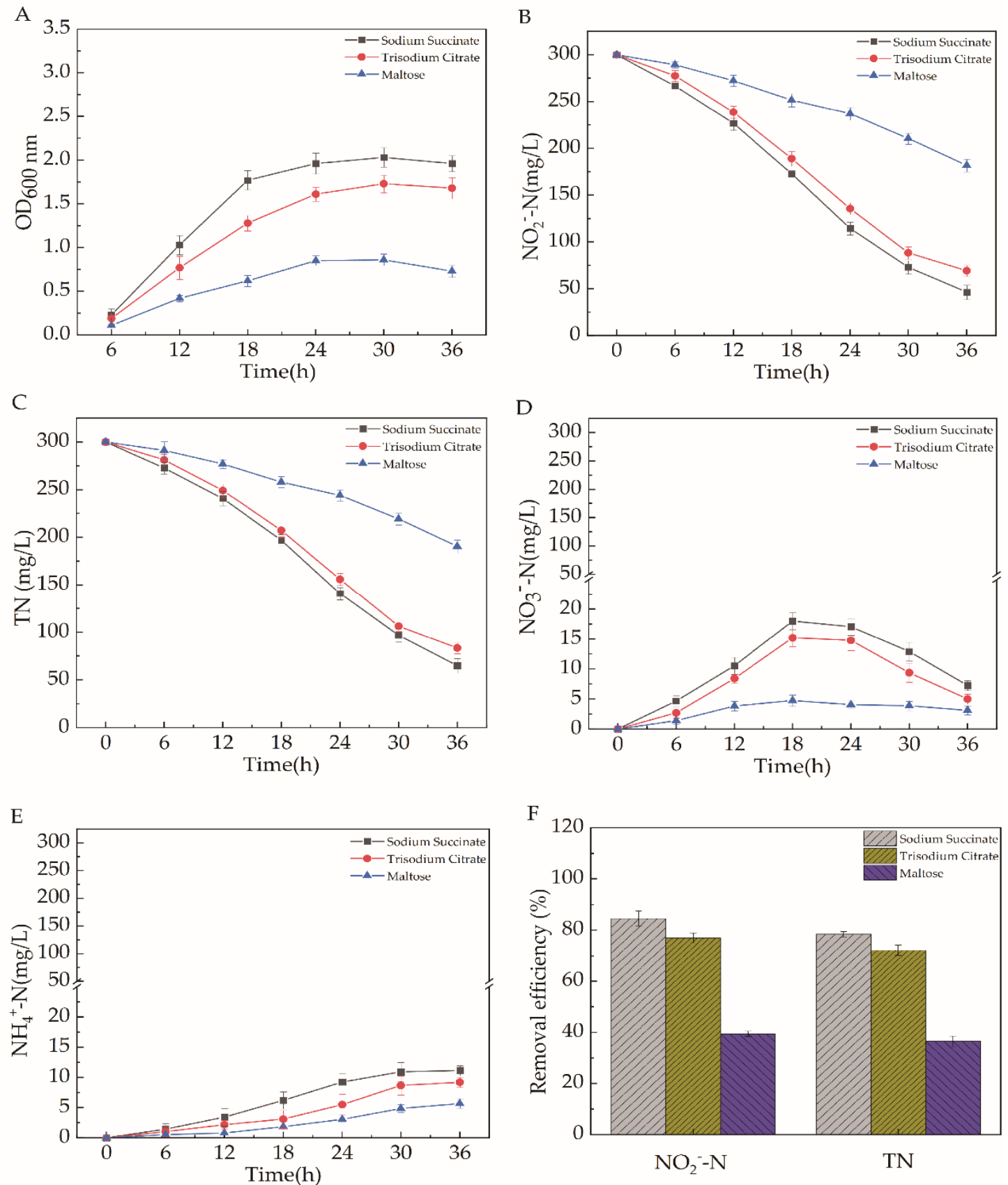

Figure 5. Nitrogen reduction-related values of strain F2 under different carbon source conditions: $\mathrm{OD}_{600}(\mathbf{A}), \mathrm{NO}_{2}{ }^{-}-\mathrm{N}(\mathbf{B})$, $\mathrm{TN}(\mathbf{C}), \mathrm{NO}_{3}{ }^{-}-\mathrm{N}(\mathbf{D})$ and $\mathrm{NH}_{4}{ }^{+}-\mathrm{N}(\mathbf{E})$, under $36 \mathrm{~h}$ of growth; $\mathrm{NO}_{2}{ }^{-}-\mathrm{N}$ and $\mathrm{TN}$ removal efficiency $(\mathbf{F})$. 
A

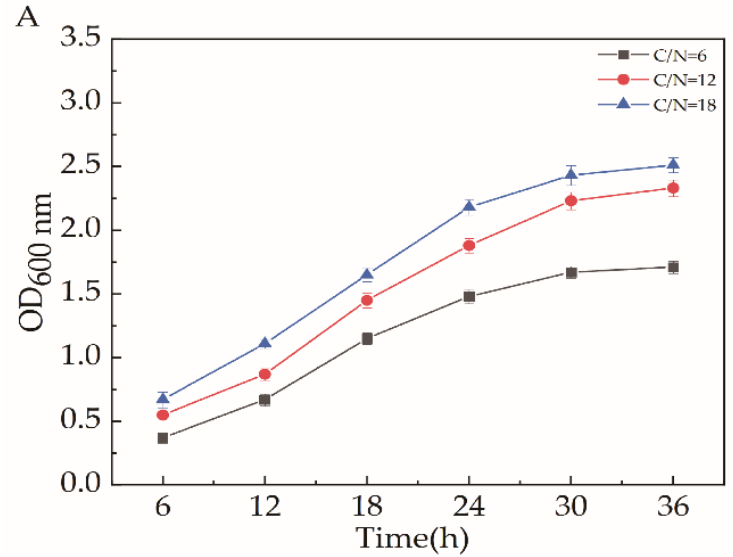

C

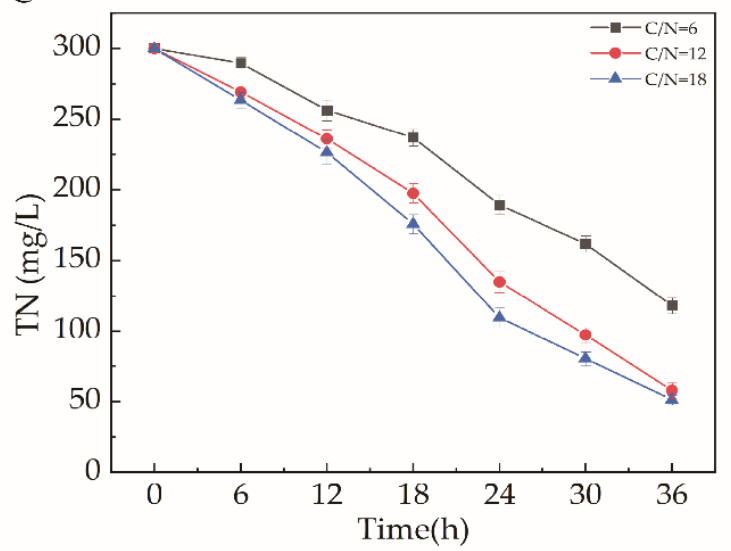

E

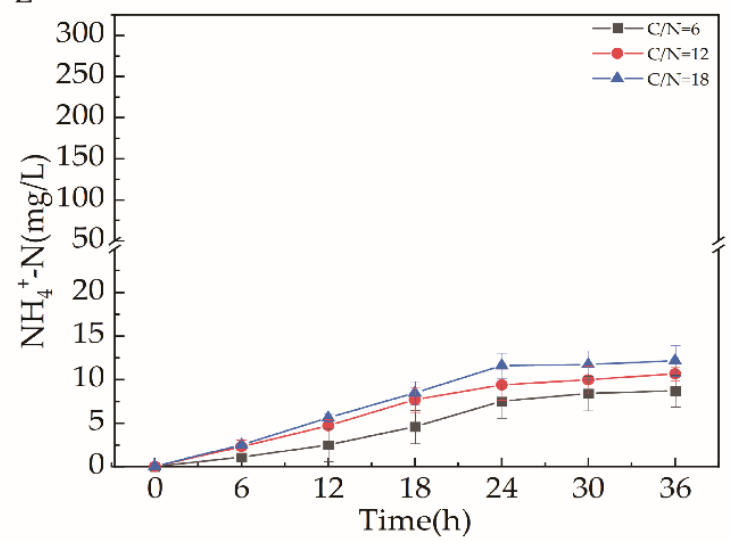

B

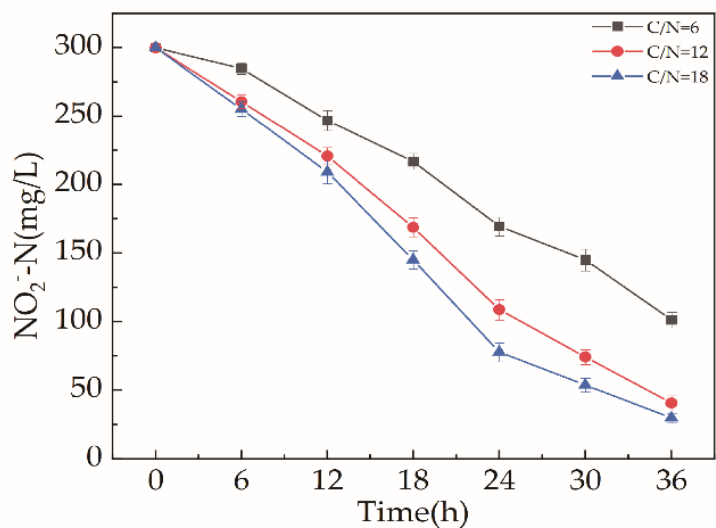

$\mathrm{D}$

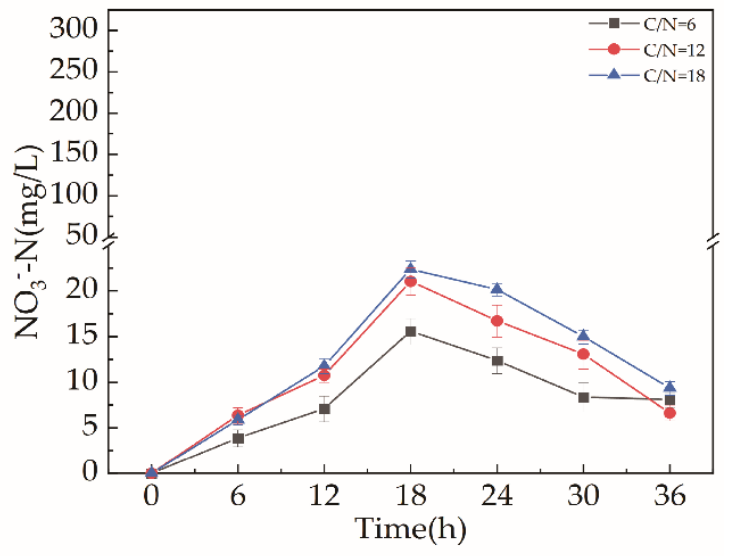

$\mathrm{F}$

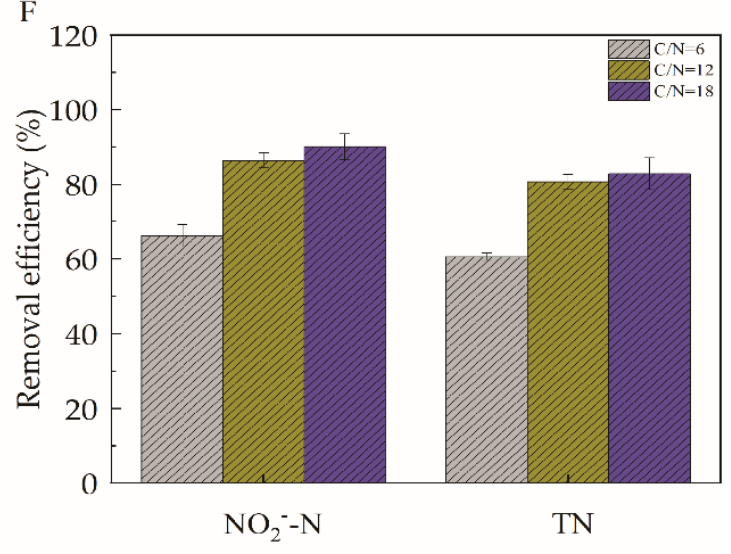

Figure 6. Nitrogen reduction-related values of strain $\mathrm{F} 2$ under different $\mathrm{C} / \mathrm{N}$ conditions: $\mathrm{OD}_{600}(\mathbf{A}), \mathrm{NO}_{2}{ }^{-}-\mathrm{N}(\mathbf{B}), \mathrm{TN}(\mathbf{C})$, $\mathrm{NO}_{3}{ }^{-}-\mathrm{N}(\mathbf{D})$ and $\mathrm{NH}_{4}{ }^{+}-\mathrm{N}(\mathrm{E})$, under $36 \mathrm{~h}$ of growth; $\mathrm{NO}_{2}{ }^{-}-\mathrm{N}$ and TN removal efficiency $(\mathbf{F})$.

\subsection{3. $\mathrm{pH}$}

$\mathrm{pH}$ is an essential factor affecting microbial enzymatic activity, and most aerobic denitrifying strains prefer neutral to alkaline conditions. Low or high $\mathrm{pH}$ will affect the stability and charged state of enzymes and inhibit enzymatic activity. Low or high $\mathrm{pH}$ will also lead to hydrolysis and degradation of proteins and nucleic acids on the surface of microorganisms, affecting the uptake of nutrients by microorganisms and thus inhibiting their growth and metabolism $[22,23]$.

To investigate the effect of $\mathrm{pH}$ on the growth and denitrification efficiency of strain $\mathrm{F} 2$, the initial $\mathrm{NO}_{2}{ }^{-}-\mathrm{N}$ concentration was determined by fixing it at about $300 \mathrm{mg} / \mathrm{L}$, and the initial $\mathrm{pH}$ of the medium was set to 6.4. Strain F2 grew well in the medium with initial $\mathrm{pH}$ values of 7.2 and 8 , and both achieved more than $90 \%$ degradation of nitroso-nitrogen, 
while it barely grew in the medium with an initial $\mathrm{pH}$ of 6.4 (Figure 7A). At pH 7.2 and 8, as seen in Figure $8 \mathrm{D}, \mathrm{E}$, the pattern of variation of $\mathrm{NO}_{3}{ }^{-}-\mathrm{N}$ and $\mathrm{NH}_{4}{ }^{+}-\mathrm{N}$ was similar to that in previous experiments with no significant changes.

The experimental results indicate that strain F2 is suitable for growth and aerobic denitrification in neutral and alkaline environments, which is similar to Acinetobacter sp. HNR [24]. In reality, the $\mathrm{pH}$ of aquaculture water is generally neutral and alkaline, which indicates that strain F2 can be used practically and has a high commercial value. The following experimental medium $\mathrm{pH}$ was set to 8 .

A

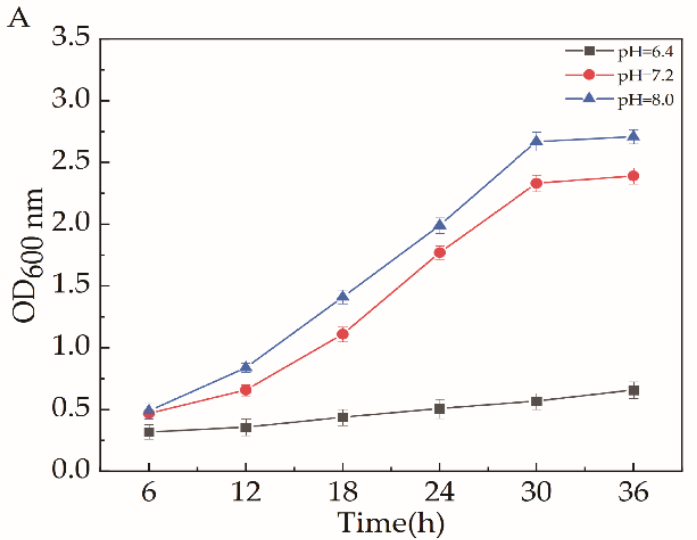

C

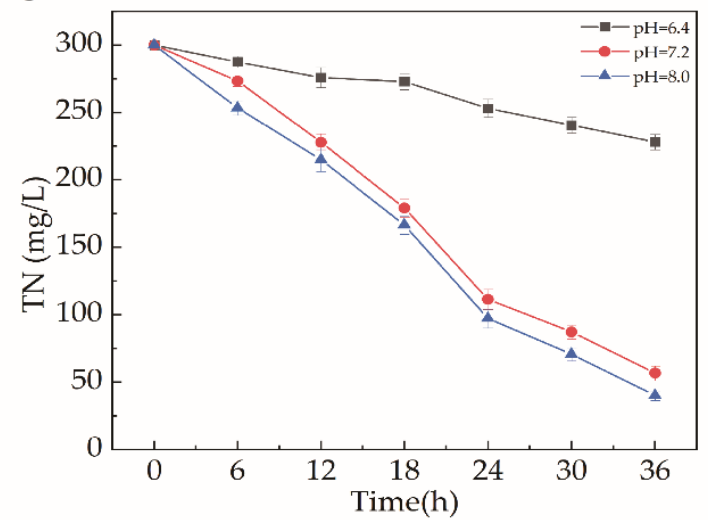

E

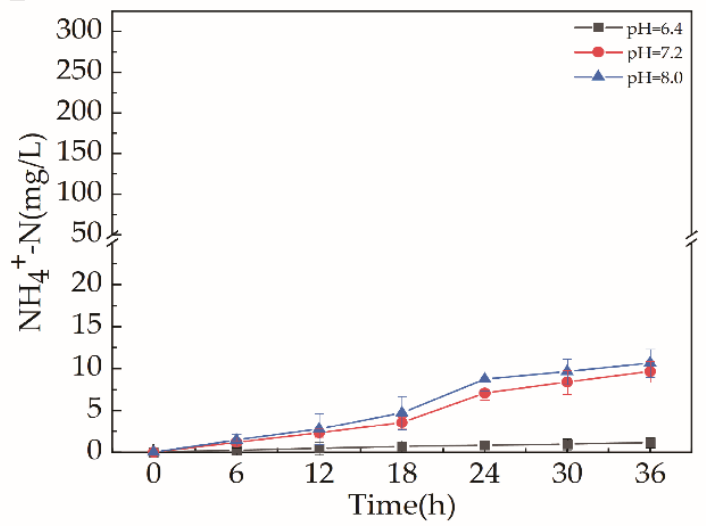

B

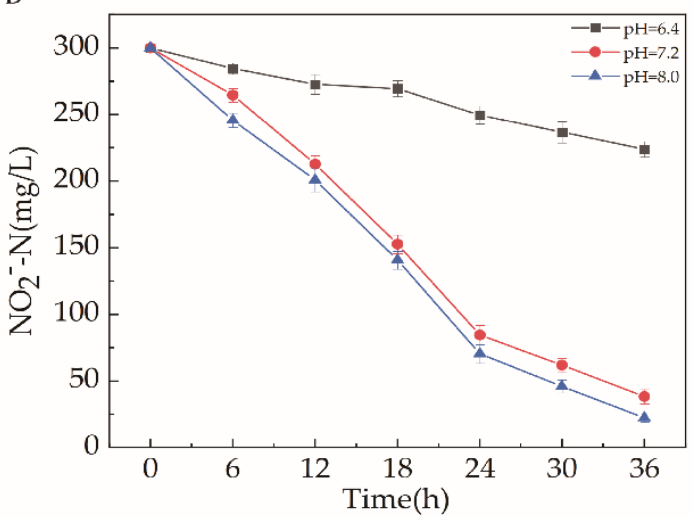

$\mathrm{D}$

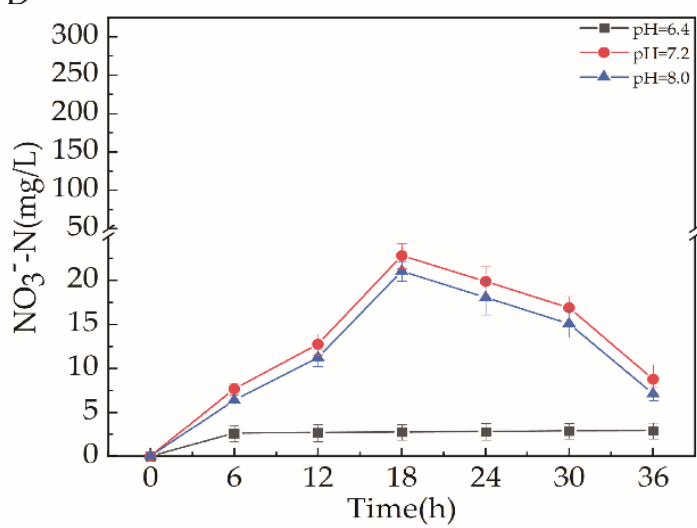

$\mathrm{F}$

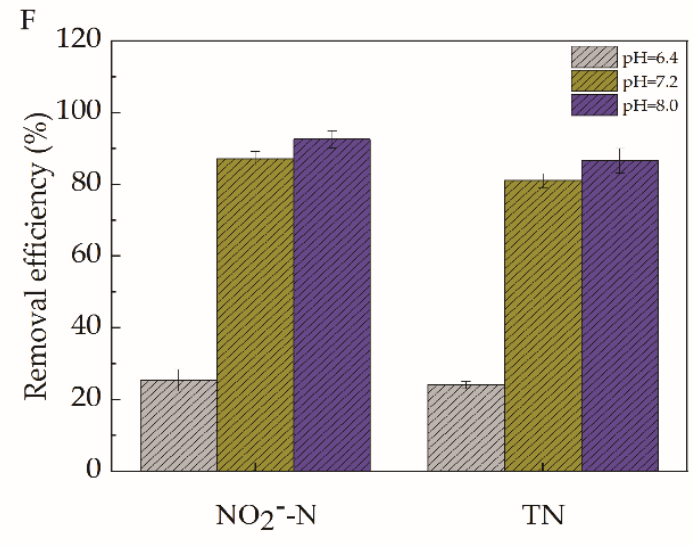

Figure 7. Nitrogen reduction-related values of strain $\mathrm{F} 2$ under different $\mathrm{pH}$ conditions: $\mathrm{OD}_{600}(\mathbf{A}), \mathrm{NO}_{2}{ }^{-}-\mathrm{N}(\mathbf{B}), \mathrm{TN}(\mathbf{C})$, $\mathrm{NO}_{3}{ }^{-}-\mathrm{N}(\mathbf{D})$ and $\mathrm{NH}_{4}{ }^{+}-\mathrm{N}(\mathrm{E})$, under $36 \mathrm{~h}$ of growth; $\mathrm{NO}_{2}{ }^{-}-\mathrm{N}$ and TN removal efficiency $(\mathbf{F})$. 

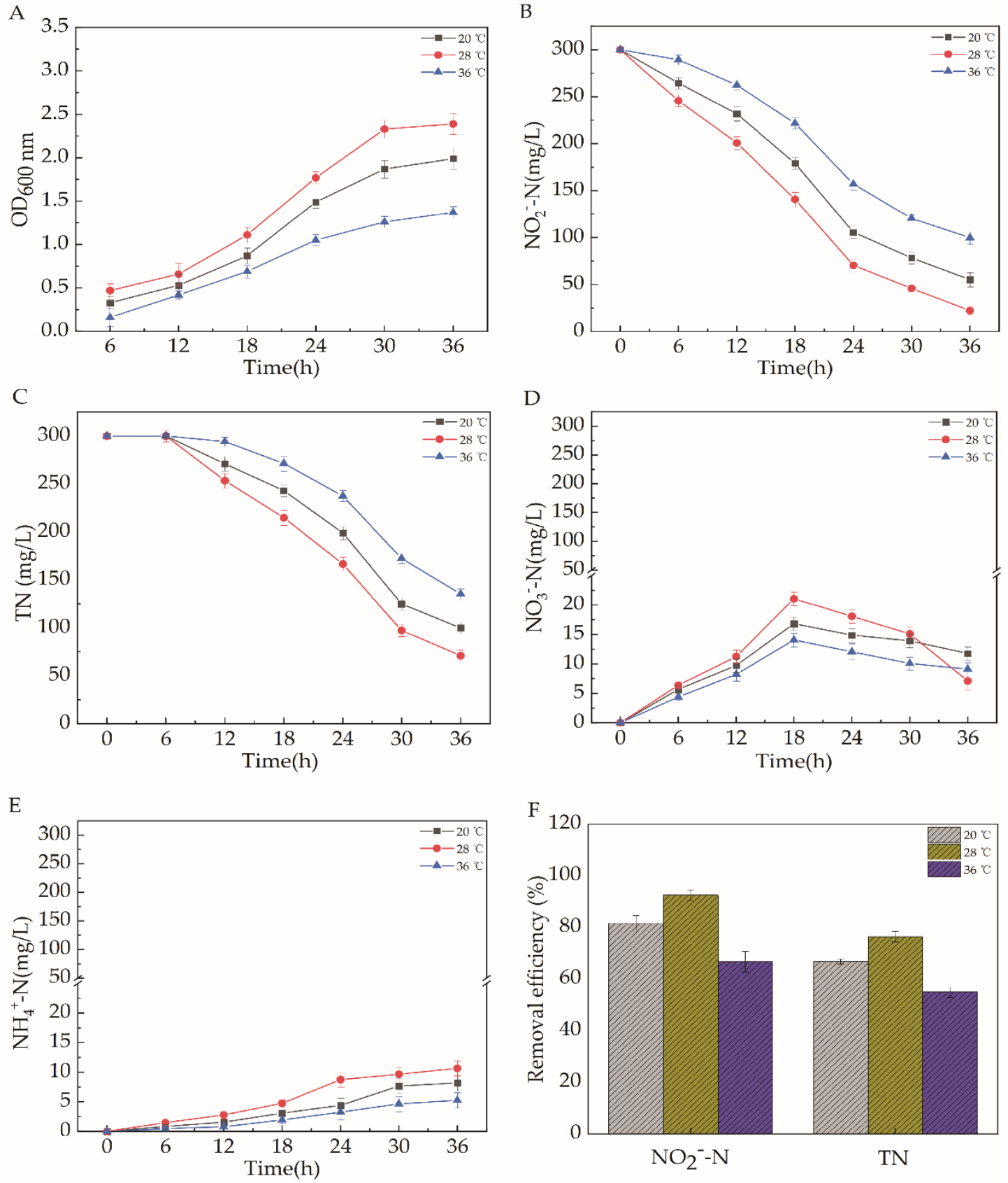

Figure 8. Nitrogen reduction-related values of strain $\mathrm{F} 2$ under different temperature conditions: $\mathrm{OD}_{600}(\mathbf{A}), \mathrm{NO}_{2}{ }^{-}-\mathrm{N}(\mathbf{B})$, $\mathrm{TN}(\mathbf{C}), \mathrm{NO}_{3}{ }^{-}-\mathrm{N}(\mathbf{D})$ and $\mathrm{NH}_{4}{ }^{+}-\mathrm{N}(\mathrm{E})$, under $36 \mathrm{~h}$ of growth; $\mathrm{NO}_{2}{ }^{-}-\mathrm{N}$ and $\mathrm{TN}$ removal efficiency $(\mathbf{F})$.

\subsubsection{Temperature}

Temperature affects the growth and enzymatic reactions of microorganisms and directly determines the efficiency of denitrification. Usually, high temperature leads to the denaturation of nucleic acids or proteins in the strain, while low temperature inhibits enzymatic activity, thus reducing the metabolic activity of denitrifying bacteria and leading to failure of nitrite reduction $[25,26]$.

It was seen that the growth of strain $\mathrm{F} 2$ became slow at $36{ }^{\circ} \mathrm{C}$ (Figure $8 \mathrm{~A}$ ), and the ability to degrade nitrite nitrogen appeared to decrease, indicating that high temperature was not conducive to the growth of the strain and its denitrification. The reason for this phenomenon may be that high temperature has a destructive effect on nitrite reductase, so the denitrification efficiency of strain F2 was somewhat inhibited. At $20^{\circ} \mathrm{C}$ and $28^{\circ} \mathrm{C}$, the strain could grow well and degrade nitrite nitrogen by aerobic denitrification. The denitrifi- 
cation efficiency of strain $\mathrm{F} 2$ was significantly higher at $28^{\circ} \mathrm{C}$ than at other temperatures, so the optimum temperature of strain F2 should be judged to be around $28^{\circ} \mathrm{C}$. At this time, the denitrification rate of strain F2 for nitrite nitrogen reached $92.54 \%$ (Figure $8 \mathrm{~F}$ ). The degradation of other nitrogen sources was similar to the previous phenomena, and no significant differences were found. This was similar to P. stutzeri ZF31 [27] and Pseudomonas mendocina GL6 [28]. The strain F2 still had better growth and no obvious reduction in the ability to degrade nitrite nitrogen at $20^{\circ} \mathrm{C}$, indicating that the strain can perform some degree of denitrification at low temperatures, which is similar to Acinetobacter sp. HA2 [29]. These results show that strain $\mathrm{F} 2$ has great potential for application in wastewater treatment and aquaculture, and the suitable temperature range for denitrification of strain F2 is consistent with the temperature variation range of aquaculture water.

\subsubsection{Dissolved Oxygen (DO)}

Dissolved oxygen affects the aerobic denitrification reaction process through the inhibition of denitrifying enzyme synthesis, activity, or competition with nitrate for electron donors and is essential for bacterial denitrification performance [30]. The concentration of DO directly affects the growth and denitrification activity of aerobic denitrifying bacteria, and the aerobic denitrification mechanism varies greatly among strains. Therefore, further studies are necessary [9]. In this work, the concentration of dissolved oxygen in the medium was altered by regulating the shaker speed, and the concentration of dissolved oxygen increased with the increase in the shaker speed. When the shaker speed was $150 \mathrm{rpm}$, the DO level in the culture medium was measured to be about $7 \mathrm{mg} / \mathrm{L}$, and the DO content increased by $1 \mathrm{mg} / \mathrm{L}$ for every $30 \mathrm{rpm}$ of shaker speed.

The experimental results indicate that the dissolved oxygen threshold of strain F2 is extremely high, which indicates that the strain has a high tolerance to oxygen; that is, it still shows good denitrification ability under high dissolved oxygen conditions. The increase in DO content did not significantly increase the biomass, but the denitrification performance of strain F2 was significantly improved, with a nitrite nitrogen removal rate up to $98.67 \%$ and a total nitrogen removal rate reaching $95.69 \%$ (Figure 9F). The degradation rate of nitrite nitrogen was improved compared to the previous degradation rate, and the change in ammonia nitrogen level was not very obvious.

In aquaculture, dissolved oxygen in the culture water is generally maintained between 4 and $8 \mathrm{mg} / \mathrm{L}$, and according to the reported aerobic denitrifying bacteria, some strains are poorly tolerant to dissolved oxygen in the water column and have low denitrification efficiency [9]. Therefore, the aerobic denitrifying strain P. stutzeri F2 was screened in this research and still had a high denitrification rate under the dissolved oxygen condition of $9 \mathrm{mg} / \mathrm{L}$, which shows a good prospect for the degradation of nitrite nitrogen under aerobic conditions.
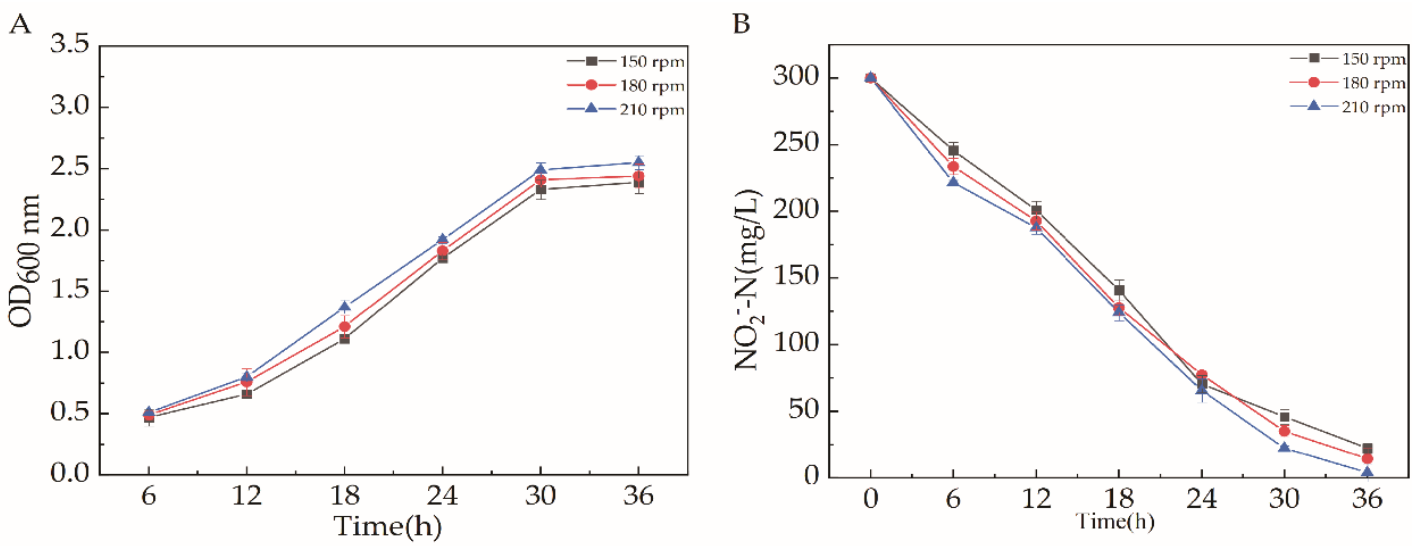

Figure 9. Cont. 
C

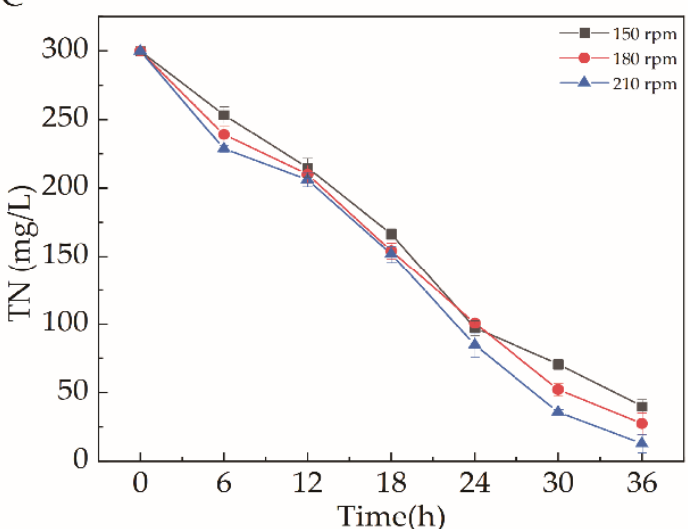

$\mathrm{E}$

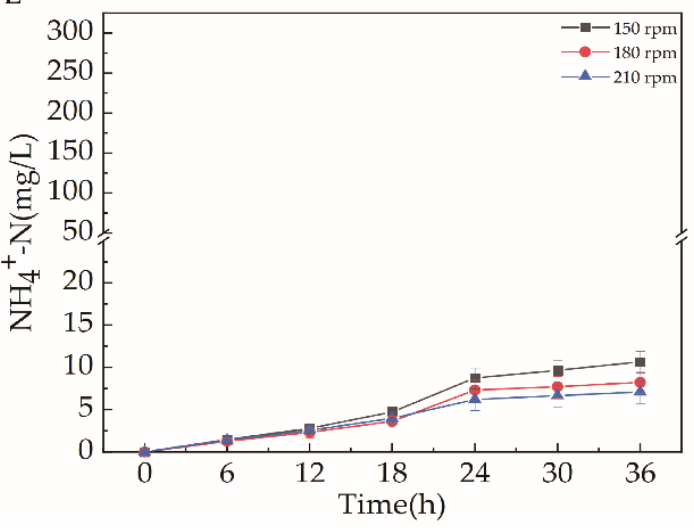

$\mathrm{D}$

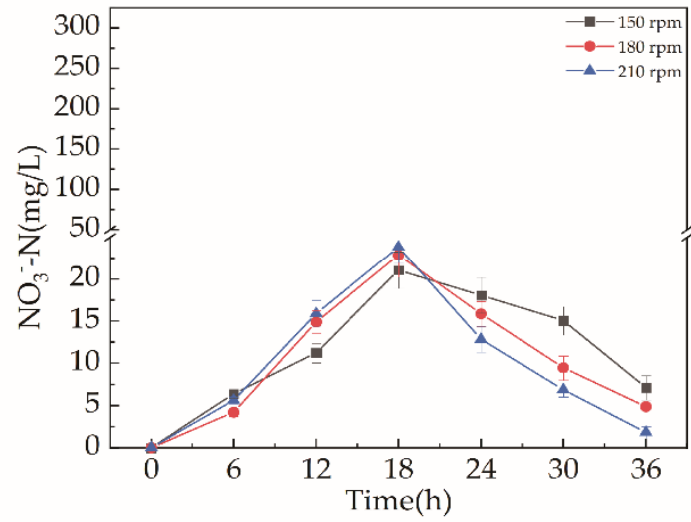

F

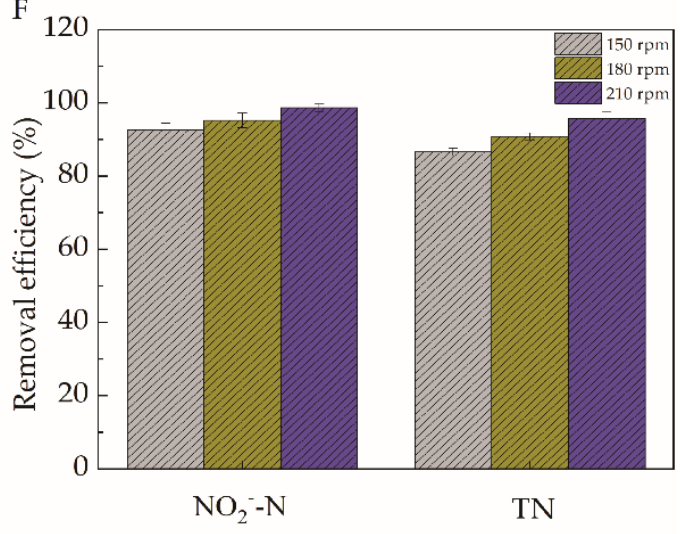

Figure 9. Nitrogen reduction-related values of strain $\mathrm{F} 2$ under different temperature conditions: $\mathrm{OD}_{600}(\mathbf{A}), \mathrm{NO}_{2}{ }^{-}-\mathrm{N}(\mathbf{B})$, $\mathrm{TN}\left(\right.$ C), $\mathrm{NO}_{3}{ }^{-}-\mathrm{N}(\mathbf{D})$ and $\mathrm{NH}_{4}{ }^{+}-\mathrm{N}(\mathrm{E})$, under $36 \mathrm{~h}$ of growth; $\mathrm{NO}_{2}{ }^{-}-\mathrm{N}$ and $\mathrm{TN}$ removal efficiency $(\mathbf{F})$.

\section{Materials and Methods}

\subsection{Media}

The basic denitrification medium (DM) [31] with the following composition (/L) was used in this study: $5.64 \mathrm{~g}$ of $\mathrm{Na}_{3} \mathrm{C}_{6} \mathrm{H}_{5} \mathrm{O}_{7} ; 1.5 \mathrm{~g}$ of $\mathrm{KH}_{2} \mathrm{PO}_{4} ; 0.42 \mathrm{~g}$ of $\mathrm{Na}_{2} \mathrm{HPO}_{4} ; 0.1 \mathrm{~g}$ of $\mathrm{MgSO}_{4} \cdot 7 \mathrm{H}_{2} \mathrm{O} ; 1.5 \mathrm{~g}$ of $\mathrm{NaNO}_{2} ; \mathrm{pH}$ was adjusted to 7 . DM medium was used for bacterial enrichment, isolation, and shake flask fermentation production experiments, and agar plates were prepared from DM containing $20 \mathrm{~g}$ of agar per liter. All media were autoclaved at $121{ }^{\circ} \mathrm{C}$ for $30 \mathrm{~min}$ before use. The reagent quality of the carbon and nitrogen sources was varied according to the experimental needs, all reagents are from Aladdin Reagent (Shanghai, China) Co.

\subsection{Strain Screening and Identification}

First, $5 \mathrm{~mL}$ of fresh sludge (Fujian DBN Aquatic Science and Technology Group CO., Zhangzhou, China) from the bottom of the aquaculture pond was transferred to a $250 \mathrm{~mL}$ conical flask with $100 \mathrm{~mL}$ of sterile water, glass beads were added, and the activated sludge was dispersed at $28^{\circ} \mathrm{C}$ and $150 \mathrm{rpm}$ shaking speed for $1 \mathrm{~h}$. Then, the suspension in the $1 \mathrm{~mL}$ conical flask was transferred to a $250 \mathrm{~mL}$ conical flask containing $100 \mathrm{~mL}$ DM culture medium and incubated at $28^{\circ} \mathrm{C}$ and $150 \mathrm{rpm}$ with shaking for $36 \mathrm{~h}$. After repeating enrichment three times, the suspension was picked up with an inoculating ring and scribed on a DM plate. After repeating isolation and purification three times, individual colonies were selected and inoculated in DM medium and incubated at $28^{\circ} \mathrm{C}$ and $150 \mathrm{rpm}$ under fermentation conditions. The removal efficiency of $\mathrm{NO}_{2}{ }^{-}-\mathrm{N}$ and $\mathrm{TN}$ in $\mathrm{DM}$ was measured separately to determine the aerobic denitrification ability of the isolates. Finally, 10 purified strains with aerobic denitrification ability were obtained by repeated delineation and 
determination of aerobic denitrification ability, and these strains were numbered F1-F10, then stored in storage tubes containing $50 \%$ glycerol in a $-40{ }^{\circ} \mathrm{C}$ refrigerator. The strain with the highest TN removal rate was named F2.

The 16S rRNA gene of strain F2 was amplified using universal primer 27F/1492R, and the amplification was completed. The sequences were analyzed and compared in the NCBI database, and 16S rRNA gene sequences of closely related species within the same genus were selected to construct a phylogenetic tree using MEGA (version 7.0, Mega Limited, Auckland, New Zealand) software.

\subsection{Targeted Domestication of Strains and Detection of Nitrogen Reduction}

Bacteria were dipped from the bailout tubes with an inoculating loop, graded and delineated on LB plates, and incubated in an inverted incubator at $28{ }^{\circ} \mathrm{C}$. After clear colonies grew, individual colonies were picked out and inoculated into a $50 \mathrm{~mL}$ conical flask containing $10 \mathrm{~mL} \mathrm{LB}$ medium and incubated for $12 \mathrm{~h}$ at $28^{\circ} \mathrm{C}$ and $150 \mathrm{rpm}$ with shaking. Furthermore, $6 \%$ of the bacterial solution washed with sterile saline was inoculated into $\mathrm{NO}_{2}{ }^{-}-\mathrm{N}$ denitrification medium at a concentration of $300 \mathrm{mg} / \mathrm{L}$ in a $250 \mathrm{~mL}$ conical shaker containing $50 \mathrm{~mL}$ of liquid for $24 \mathrm{~h}$. Then, $6 \%$ of the bacterial solution was inoculated into the next $\mathrm{NO}_{2}{ }^{-}-\mathrm{N}$ concentration of $300 \mathrm{mg} / \mathrm{L}$ fresh denitrification medium. Each concentration cycle was transferred several times until the strain $\mathrm{F} 2$ adapted to this concentration environment. Through several pre-experiments, the $\mathrm{NO}_{2}{ }^{-}-\mathrm{N}$ concentration was gradually increased and finally determined so that the F2 strain in the $\mathrm{NO}_{2}{ }^{-}-\mathrm{N}$ concentration of $500 \mathrm{mg} / \mathrm{L}$ DM medium growth $\mathrm{OD}_{600}$ reached above 1 , and the domestication was stopped. The strains were preserved, and the domesticated mutant strains were used for the later nitrogen reduction performance tests. To evaluate the aerobic nitrite removal capacity, growth $\left(\mathrm{OD}_{600}\right), \mathrm{NO}_{2}{ }^{-}-\mathrm{N}, \mathrm{TN}, \mathrm{NO}_{3}{ }^{-}-\mathrm{N}$, and $\mathrm{NH}_{4}{ }^{+}-\mathrm{N}$ indicators were measured by regular sampling.

\subsection{Single Factor Affecting Aerobic Denitrification}

An inoculation loop was used to dip the bacteria from the preserved strain tube in to the LB plate for graded delineation. This was incubated upside down in at $28^{\circ} \mathrm{C}$ until a clear single colony was grown. A single colony was placed into a $50 \mathrm{~mL}$ conical flask with $10 \mathrm{~mL} \mathrm{LB}$ culture medium, incubated at $28^{\circ} \mathrm{C}$, with $150 \mathrm{rpm}$ shaker activation for $12 \mathrm{~h}$. Then, $6 \%$ of the bacterial solution washed with sterile saline was inoculated into a $50 \mathrm{~mL}$ $\mathrm{DM}$ culture medium in a $250 \mathrm{~mL}$ conical flask. The culture conditions were $28{ }^{\circ} \mathrm{C}$ and $150 \mathrm{rpm}$, while the culture solution $\mathrm{C} / \mathrm{N}$ mass ratio was adjusted to 10:1 when different carbon sources were explored. Other conditions were explored, and only the exploration conditions were changed. The $\mathrm{OD}_{600}$ was sampled periodically, and the concentrations of $\mathrm{TN}, \mathrm{NO}_{2}{ }^{-}-\mathrm{N}, \mathrm{NO}_{3}{ }^{-}-\mathrm{N}$, and $\mathrm{NH}_{4}{ }^{+}-\mathrm{N}$ in the supernatant were measured.

\subsection{Analytical Methods}

The absorbance (A) of the bacterial growth was determined by the absorbance method using the absorbance values, which were measured at $600 \mathrm{~nm}$. The determination of $\mathrm{NO}_{3}{ }^{-}-\mathrm{N}, \mathrm{NH}_{4}{ }^{+}-\mathrm{N}$, and $\mathrm{NO}_{2}{ }^{-}-\mathrm{N}$ was carried out according to the literature. $\mathrm{pH}$ values were determined using a Mettler Toledo Delta $320 \mathrm{pH}$ meter (Mettler-Toledo, Schwerzenbach, Switzerland). Intracellular $\mathrm{N}$ was estimated by multiplying biomass with the nitrogen percentage in biomass [32,33]. The nitrogen percentage in the biomass was estimated by $\mathrm{C}_{5} \mathrm{H}_{7} \mathrm{NO}_{2}$. Organic $\mathrm{N}$, which is mainly released from the bacterial decay or extracellular materials, was calculated by subtracting final $\mathrm{NO}_{3}{ }^{-}-\mathrm{N}, \mathrm{NO}_{2}{ }^{-}-\mathrm{N}$, and $\mathrm{NH}_{4}{ }^{+}-\mathrm{N}$ from final $\mathrm{TN}$. The initial nitrogen concentration was labeled $\mathrm{TN}_{0}$. Gaseous $\mathrm{N}$ was calculated by subtracting final $\mathrm{TN}$ and intracellular $\mathrm{N}$ from initial $\mathrm{TN}_{0}$. The concentration of organic $\mathrm{N}$ and gaseous $\mathrm{N}$ was calculated as follows:

$$
\begin{gathered}
\text { Organic } \mathrm{N}=\mathrm{TN}-\mathrm{NO}_{2}{ }^{-}-\mathrm{N}-\mathrm{NO}_{3}{ }^{-}-\mathrm{N}-\mathrm{NH}_{4}{ }^{+}-\mathrm{N} \\
\text { Gaseous } \mathrm{N}=\mathrm{TN}_{0}-\mathrm{TN}-\text { Intracellular } \mathrm{N}
\end{gathered}
$$




\section{Conclusions}

Eventually, the most suitable conditions for each factor were selected, and the aquaculture wastewater was treated in several simulations. Strain F2 has great potential for application in wastewater treatment and aquaculture. Generally, after $36 \mathrm{~h}$ of fermentation treatment, the removal rates of both $\mathrm{NO}_{2}{ }^{-}-\mathrm{N}$ and $\mathrm{TN}$ reached more than $98 \%$, respectively, with the conversion rate of gaseous nitrogen reaching more than $70 \%$, indicating that strain F2 has good prospects for practical application in reducing nitrogen sources in water bodies.

Author Contributions: Conceptualization, W.F. and Q.W.; methodology, W.F., S.C., Y.W. (Yunshuang Wang), Y.W. (Yaru Wang) and P.D.; software, W.F. and Q.W.; validation, W.F., G.Y., X.Z. and Z.R.; formal analysis, W.F.; investigation, W.F. and Q.W.; resources, X.Z. and Z.R.; data curation, W.F. and Q.W.; writing—original draft preparation, W.F.; writing—review and editing, W.F., Q.W., X.Z. and Z.R.; visualization, X.Z.; supervision, C.L., X.Z. and Z.R.; project administration, W.F., X.Z. and Z.R.; funding acquisition, X.Z. and Z.R. All authors have read and agreed to the published version of the manuscript.

Funding: This work was supported by the National Key Research and Development Program of China (no. 2021YFC2100900), National Natural Science Foundation of China (no. 32171471), Key Research and Development Program of Ningxia Hui Autonomous Region (no. 2020BFH01001), Foundation of Fujian Key Laboratory of Functional Aquafeed and Culture Environment Control (no. FACE20200003), Program of the Key Laboratory of Industrial Biotechnology, Ministry of Education, China (no. KLIB-KF202103), 111 Project (111-2-06), and Jiangsu province "Collaborative Innovation Center for Advanced Industrial Fermentation" industry development program.

Conflicts of Interest: The authors declare no conflict of interest.

\section{References}

1. Emparanza, E. Problems affecting nitrification in commercial RAS with fixed-bed biofilters for salmonids in Chile. Aquac. Eng. 2009, 41, 91-96. [CrossRef]

2. Saliling, W.; Westerman, P.W.; Losordo, T.M. Wood chips and wheat straw as alternative biofilter media for denitrification reactors treating aquaculture and other wastewaters with high nitrate concentrations. Aquac. Eng. 2007, 37, 222-233. [CrossRef]

3. Manju, N.J.; Deepesh, V.; Achuthan, C.; Rosamma, P.; Singh, I. Immobilization of nitrifying bacterial consortia on wood particles for bioaugmenting nitrification in shrimp culture systems. Aquaculture 2009, 294, 65-75. [CrossRef]

4. Ahmed, M.B.; Zhou, J.L.; Ngo, H.H.; Guo, W.; Thomaidis, N.S.; Xu, J. Progress in the biological and chemical treatment technologies for emerging contaminant removal from wastewater: A critical review. J. Hazard. Mater. 2016, 323, $274-298$. [CrossRef]

5. Zhu, R.; Wang, S.; Li, J.; Wang, K.; Miao, L.; Ma, B.; Peng, Y. Biological nitrogen removal from landfill leachate using anaerobicaerobic process: Denitritation via organics in raw leachate and intracellular storage polymers of microorganisms. Bioresour. Technol. 2013, 128, 401-408. [CrossRef] [PubMed]

6. Robertson, L.A.; Kuenen, J.G. Thiosphaera pantotropha gen. nov. sp. nov., a Facultatively Anaerobic, Facultatively Autotrophic Sulphur Bacterium. Microbiology 1983, 129, 2847-2855. [CrossRef]

7. Díaz-Cruz, M.; García-Galán, M.; Guerra, P.; Jelic, A.; Postigo, C.; Eljarrat, E.; Farré, M.; Alda, M.; Petrovic, M.; Barceló, D. The Handbook of Environmental Chemistry. TrAC Trends Anal. Chem. 2009, 28, 1263-1275. [CrossRef]

8. Pai, S.L.; Chong, N.M.; Chen, C.H. Potential applications of aerobic denitrifying bacteria as bioagents in wastewater treatment. Bioresour. Technol. 1999, 68, 179-185. [CrossRef]

9. Diekmann, T.L.H. Aerobic denitrification by a newly isolated heterotrophic bacterium strain TL1. Biotechnol. Lett. 1997, 19, 1157-1159.

10. Chen, F.; Xia, Q.; Ju, L.K. Aerobic Denitrification of Pseudomonas aeruginosa Monitored by Online NAD(P)H Fluorescence. Appl. Environ. Microbiol. 2003, 69, 6715-6722. [CrossRef]

11. Kim, J.K.; Park, K.J.; Cho, K.S.; Nam, S.W.; Park, T.J.; Bajpai, R. Aerobic nitrification-denitrification by heterotrophic Bacillus strains. Bioresour. Technol. 2005, 96, 1897-1906. [CrossRef]

12. Wang, H.Y.; Fang, M.A.; Zhou, D.D. The Mechanism and Research Progress of Synchronous Nitrification and Aerobic Denitrification in Biological Nitrogen Removal. Sichuan Environ. 2004, 36, 11-14.

13. Bing, L.I.; Lin, W.T. Study on Aerobic Denitrification Characteristics of Bacillus Strain D5. J. Hydroecology 2009, 3, 48-52.

14. Zufarzaana, Z.; Zaharin, A.A.; Shamsuddin, Z.H.; Kamil, Y.M. Cation Dependence, pH Tolerance, and Dosage Requirement of a Bioflocculant Produced by Bacillus spp. UPMB13: Flocculation Performance Optimization through Kaolin Assays. Sci. World J. 2012, 2012, 495659. 
15. Zhao, B.; Cheng, D.Y.; Tan, P.; An, Q.; Guo, J.S. Characterization of an aerobic denitrifier Pseudomonas stutzeri strain XL-2 to achieve efficient nitrate removal. Bioresour. Technol. 2017, 250, 564-573. [CrossRef] [PubMed]

16. Li, W.F.; Fu, L.Q.; Deng, B.; Chen, N.N.; Zhou, X.X. Identification and denitrification characteristics of an aerobic denitrifier. Huan Jing Ke Xue = Huanjing Kexue 2011, 32, 2403-2408.

17. Tian, X.; Cheng, Y.; Zhang, Y.; Shi, X. Isolation, identification and nitrogen removal characteristics of a heterotrophic nitrificationaerobic denitrification bacterium. Chin. J. Environ. Eng. 2017.

18. Chen, L.; Bai, J.; Zhao, Y.; Tian, W.; Zhang, Y.; Dang, J.; Li, K. Identification and denitrification characteristics of an aerobic denitrifier in estuary phragmites wetland. Acta Microbiol. Sin. 2016, 56, 1314-1325.

19. Xiu, H.; Zhu, Z.; Ding, A.; Zheng, L. Isolation and identification of the aerobic denitrifying strain DF2 and its physiological and biochemical analysis. Ecol. Environ. Sci. 2011, 20, 1307-1314.

20. Huang, H.K.; Tseng, S.K. Nitrate reduction by Citrobacter diversus under aerobic environment. Appl. Microbiol. Biotechnol. 2001, 55, 90-94. [CrossRef]

21. Patureau, D.; Bernet, N.; Moletta, R. Effect of oxygen on denitrification in continuous chemostat culture with Comamonas sp. SGLY2. J. Ind. Microbiol. 1996, 16, 124-128. [CrossRef]

22. Gupta, A.B. Thiosphaera pantotropha: A sulphur bacterium capable of simultaneous heterotrophic nitrification and aerobic denitrification. Enzym. Microb. Technol. 1997, 21, 589-595. [CrossRef]

23. Timmermans, P.; Haute, A.V. Denitrification with methanol-fundamental study of the growth and denitrification capacity of Hyphomicrobium spp. Water Res. 1983, 17, 1249-1255. [CrossRef]

24. Zhao, B.; Yi, L.H.; Hughes, J.; Xiao, F.Z. Heterotrophic nitrogen removal by a newly isolated Acinetobacter calcoaceticus HNR. Bioresour. Technol. 2010, 101, 5194-5200. [CrossRef]

25. Song, Z.F.; An, J.; Fu, G.H.; Yang, X.L. Isolation and characterization of an aerobic denitrifying Bacillus sp. YX-6 from shrimp culture ponds. Aquaculture 2011, 319, 188-193. [CrossRef]

26. Joo, H.S.; Hirai, M.; Shoda, M. Characteristics of ammonium removal by heterotrophic nitrification-aerobic denitrification by Alcaligenes faecalis No. 4. J. Biosci. Bioeng. 2005, 100, 184-191. [CrossRef]

27. Huang, T.; Guo, L.; Zhang, H.; Su, J.; Wen, G.; Zhang, K. Nitrogen-removal efficiency of a novel aerobic denitrifying bacterium, Pseudomonas stutzeri strain ZF31, isolated from a drinking-water reservoir. Bioresour. Technol. 2015, 196, 209-216. [CrossRef]

28. Zhang, W.; Yan, C.; Shen, J.; Wei, R.; Gao, Y.; Miao, A.; Xiao, L.; Yang, L. Characterization of Aerobic Denitrifying Bacterium Pseudomonas mendocina Strain GL6 and Its Potential Application in Wastewater Treatment Plant Effluent. Int. J. Environ. Res. Public Health 2019, 16, 364. [CrossRef]

29. Ren, Y.X.; Lei, Y.; Liang, X. The characteristics of a novel heterotrophic nitrifying and aerobic denitrifying bacterium, Acinetobacter junii YB. Bioresour. Technol. 2014, 171, 1-9. [CrossRef]

30. Tiedje, J.M. Ecology of denitrification and dissimilatory nitrate reduction to ammonium. Biol. Anaerob. Microorg. 1988, 27, 179-244.

31. Guo, L.J.; Zhao, B.; An, Q.; Tian, M. Characteristics of a Novel Aerobic Denitrifying Bacterium, Enterobacter cloacae Strain HNR. Appl. Biochem. Biotechnol. 2016, 178, 947-959. [CrossRef] [PubMed]

32. Yao, S.; Ni, J.; Tao, M.; Li, C. Heterotrophic nitrification and aerobic denitrification at low temperature by a newly isolated bacterium, Acinetobacter sp. HA2. Bioresour. Technol. 2013, 139, 80-86. [CrossRef] [PubMed]

33. Ye, J.; Zhao, B.; An, Q.; Huang, Y.S. Nitrogen removal by Providencia rettgeri strain YL with heterotrophic nitrification and aerobic denitrification. Environ. Technol. 2016, 37, 2206-2213. [CrossRef] [PubMed] 